\title{
Review: Lee Grieveson, Cinema and the Wealth of Nations: Media, Capital, and the Liberal World
}

System

Maria Fernanda Miño Puga

DOI: $10.15664 /$ fcj.v0i18.2264

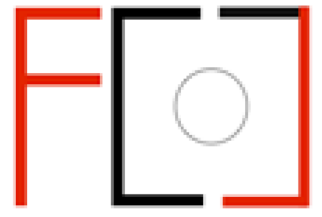

Frames Cinema Journal ISSN 2053-8812 


\section{Cinema and the Wealth of Nations. Media, Capital, and the Liberal World System By Lee Grieveson University of California Press, 2018 Reviewed by Maria Fernanda Miño Puga, University of St Andrews}

Lee Grieveson's Cinema and the Wealth of Nations. Media, Capital, and the Liberal World System (2018) constitutes a must-read text for those interested in media history and its relationship to wider power structures. The title references The Wealth of Nations by Adam Smith, first published in 1776 , containing the basic principles that later defined liberal capitalism. The author parallels this political ideology with the development of cinema and accompanying media (radio and television), both emerging at a moment in which power dynamics were gradually shifting from a British imperial dominance to an American trade hegemony. In doing so, Grieveson examines a corporate media structure that both symbolizes and disseminates free market ideas, limited state interventionism, and consumerism. The author uses this analysis to draw attention to the current state of affairs, offering a direct call to action for those involved in film research, and other related fields.

Consisting of 465 pages, the book is divided into thirteen chapters, a list of notes, and a complementary Sources and Bibliography section. These last two segments, encompassing almost a third of the page count, attest for the nuance in research provided by Grieveson. The text moves effortlessly through a vast array of information, untangling historical events, technological advances, political decisions, and their effects on the global economy. Grieveson chooses not to focus solely on cinema, at times prioritizing the expansion of radio (Chapter 9), television, or corporate public relations (Chapters 10 to 13), to underline the interconnectedness between these apparent distant histories. While most of the book centres on American and British cases, Grieveson is careful to also include examples from Asia, Africa, and Latin America, as a means to emphasize the scale of influence of liberal capitalism, a philosophy inevitably linked to foreign policy. 
After a detailed introduction in Chapter 1 ("The Silvers Screen and the Gold Standard"), Chapter 2 focuses on a specific event, the Panama-Pacific International Exposition in 1915. Alluding to the Panama Papers scandal (the chapter is titled "The Panama Caper"), Grieveson highlights the use of infrastructural achievement, in this case the completion of the Panama Canal, to promote capital-driven progress. Pedagogical films included in the exhibition suggests that cinema was already employed by state and private agencies to communicate a particular set of economic practices, aimed towards such progress. As Grieveson would argue, the novelty of new trade routes in international commerce became attached to the novelty of motion pictures and the ideologies communicated through them, mainly those in favour of free trade and wealth generation.

This argument is developed throughout the book, culminating in another event, the 1939 New York World's Fair, discussed in Chapter 13. But before coming full circle, Grieveson delves into a complex structure of corporate and state interests, focused on capital. Chapter 3, for instance, explores concepts like "capital world system" and "liberal political economy", here attributed to the "long century" between America's independence (and Adam Smith's publication) in 1776, and the beginning of World War I in 1914. While cinema takes a back stand in this chapter, this framework informs subsequent interpretations on statesponsored propaganda during wartime, with comparable institutions on both sides of the Atlantic, detailed in Chapter 4 (“Liberty Bonds").

The "State of Extension" in Chapter 5 includes the use of pedagogical films to promote expected codes of conduct in working class America. Networks comprised by existing organisations such as schools, universities, and churches, served as an extended arm for corporate and state film exhibition, not only influencing individual behaviour, but also fostering major infrastructural endeavours. Again, the idea of cinema fuelling capital-driven progress is reinforced by Grieveson, this time concentrating on the narratives propagated 
through these networks, studied in Chapter 6 ("The Work of Film in the Age of Fordist Mechanization”) and 7 (“The Pan-American Road to Happiness and Friendship"). According to the author, employee training films and corporate advertisement engaged in similar strategies as state and international lobbying, converging in "good neighbour" narratives and the socalled American dream. As Grieveson summarizes: "Policy was encoded in character and became narrative" (147).

Turning to the British scenario, a comparable assessment is concluded in Chapter 8 ("Highways of Empire"). Grieveson examines the institutions that helped circulate stateproduced media in British territories. For the author, colonies were defined by the goods they produced, with educational films projecting a particular image of the empire in order to ensure free trade and orderly compliance. It is in this context that documentary emerged as a film practice, which Grieveson expands and later associates to the League of Nations, or "League of Corporations" in Chapter 9. Through this institution, Grieveson contends that upcoming interpretations of security and freedom grew gradually appended to the establishment of free market dynamics in a liberal world order.

The last four chapters of the book move to a more localised analysis of media structures in America, and their effects on today's society. Chapter 10 ("The Silver Chains of Mimesis") reviews early theories on collective behaviour or 'mimesis', and how these were later applied to corporate media strategies by means of public relations. Grieveson contends that PR offices represented an example of media convergence, carefully designed to secure capital during the studio system era. In this sense, Chapter 11 (“The Golden Harvest of the Silver Screen”) exposes monopolistic practices in film production and exhibition, with banking investors heavily influencing the development of sound and theatrical distribution. Corporate public relations are also mentioned in Chapter 12 ("Welfare Media"), in the wake of the 1929 stock market collapse, and Franklin D. Roosevelt's New Deal. Grieveson suggests that a more 
"militant" capitalism surfaced during this period, aimed towards maintaining a state-free corporate system, while also neutralising the red scare of communism.

Certainly, Grieveson's critique of liberal capitalism is evident throughout the book but made explicitly clear in Chapter 13 (“The World of Tomorrow - Today!"). The author does not hesitate in using terms like "manufacturing consent" and "control of populations" when referring to capitalist media practices. Fast-forwarding to recent events, including the Cold War and the resulting "neoliberalisation of media", Grieveson challenges the reader to take a more critical and tangible stance. Particularly for those in academia, Grieveson encourages interdisciplinary discussions that move away from mere textual analysis of market-centred cinema, to also include pedagogic films and similar media circulated in broader societal contexts.

Establishing a clear position could be perceived as bias, or distant from scholarly objectivity. However, to Grieveson's credit, the book manages to offer a political view substantiated via an extensive body of evidence. While interpretations can move across the political spectrum, these findings can surely add to further studies in any related field, regardless of ideological association. Moreover, adding to a remarkable methodological and historical approach, this book can also be studied as a reflection on current affairs. The questions raised by Grieveson are valid reactions to the concerns of today's world, which surely can find echoes in academia, as well as more mainstream forums of debate. 